\title{
DEBATING THE METHODOLOGIES OF ACCOUNTING FOR FINANCIAL AND NON- FINANCIAL CONTRACTS
}

\author{
Daniël Coetsee \\ Department of Accounting, University of Johannesburg \\ dcoetsee@uj.ac.za
}

September 2007

\begin{abstract}
This article adds value to the accounting debate on the different methodologies of accounting for financial and non-financial contracts in the current and proposed new accounting pronouncements of the IASB. The paper demonstrates that significant differences exist between the recognition and measurements of non-financial contracts in terms of the traditional accrual basis of accounting and financial contracts in terms of the so-called contractual basis of accounting applied for financial instruments, even though the accounting for financial instruments is seen as an extension of the traditional accrual basis of accounting. The current IASB's projects on liabilities, revenue recognition and the conceptual framework seem to eliminate certain differences between the two methodologies, but also raise new issues on the debate of the methodologies to account for financial and non-financial contracts.
\end{abstract}

Keywords:

Accounting of contracts, accrual basis, contractual basis, executory contracts, financial instruments, measurement, performance basis, recognition, rights and obligations. 


\section{INTRODUCTION}

The March 1997 Discussion Paper: Accounting for Financial Assets and Financial Liabilities (hereafter the Financial Instrument Discussion Paper) states that the proposed accounting for financial assets and financial liabilities may be considered a natural extension of the traditional accrual accounting model, adapted to fit current business and economic circumstances (IASC, 1997:13). However, Bradbury (2003:390) states that "The focus on the contractual conditions indicates a movement away from the traditional exchange basis towards a contractual basis of accounting". The exchange basis refers to the traditional accrual basis of accounting under which the transactions in a contract and not the contract itself triggers the accounting process. This, then, raises the question of whether the accounting of financial instruments has changed the traditional accrual accounting model.

The author in this article and in an earlier article (Coetsee, 2006), demonstrates that there are indeed fundamental differences between the traditional accrual basis of accounting and the so-called contract basis of accounting for financial instruments. This is, in the author's view, one of the reasons why the International Accounting Standards Board (IASB) and the Financial Accounting Standards Board (FASB) have jointly decided to redraft the traditional accounting frameworks of both of the aforementioned Boards.

The concept of a contract basis of accounting has prompted the author to conduct research into the different means by which contracts are currently being recognised and measured for accounting purposes. The author has ascertained that the basis for recognition and measurement of financial contracts indeed differs from other contracts. Financial contracts are recognised when an entity becomes a party to the contract. In contrast, the recognition of other contracts is triggered by the transactions and events in the contracts, and not by the entering into the contract itself. Questions are thus raised about the unit of account that should be applied for different contracts as this unit determines whether contracts should be grouped at some level of aggregation, or disaggregation, rather than be measured as one contract in total (Bullen \& Crook, 2005:12).

However, in some of the current projects of the IASB, differences between the two bases of accounting for contracts, identified above, are at present under consideration for elimination in future pronouncements. For instance, under the Liabilities Project (IASB 2006a), previously referred to as non-financial liabilities, it is proposed that the recognition criteria of probability be removed for non-financial liabilities. Under the Revenue Recognition Project (IASB, 2006b) the concept of executory contracts, currently a principle in IAS 37 Provisions, Contingent Liabilities and Contingent Assets, is confirmed but certain obligations in revenue contracts are considered to be recognised before the event of performance. Lastly, under the Conceptual Framework Project (IASB, 2006c), the proposed definitions of assets and liabilities are to be amended to exclude some concepts such as "control" and "past event", concepts which have been regarded as cornerstones of the traditional accrual basis of accounting.

\section{RESEARCH OBJECTIVE AND METHODOLOGY}

The aim of the article is to add value to the accounting debate on the different methods of accounting for financial and non-financial contracts by reviewing the appropriateness of the 
implied bases in International Financial Reporting Standards (IFRS) relevant to the accounting of contracts, as well as project updates of the IASB. The fact that assets have "conceptual primacy" and that the other definitions in the Framework are built on the asset definition (Bullen \& Crook, 2005:7) are considered throughout this article.

The research in this article is limited to the recognition and measurement of financial and nonfinancial contracts and does not include derecognition or the effect on performance reporting. This article is further limited to a literature study of various IASB documents and other relevant literature.

To achieve the objective of debating the different methods of accounting for contracts, the following stages are applied in this article: (1) identify the critical principles of the traditional accrual basis of accounting as applicable to contracts; (2) critically review the principles of the accounting for financial instruments by comparing them to the principles of the traditional accrual basis of accounting; (3) critically review the changes to the accounting of contracts proposed by the IASB's Liability Project; (4) critically review the change to the accounting of contracts proposed by the IASB's Revenue Recognition Project; and finally, based on all the previous stages, (5) critically review the new definitions of assets and liabilities proposed in the joint Conceptual Framework Project.

The methodology followed is a discussion of each of the separately identified stages which will then provide an integrated conclusion. The stages are discussed in the sequence of which the related documents have been issued to demonstrate the development over time. However, for stages (3), (4) and (5) no final documents have been issued.

This article can be seen as a first step in the accounting debate surrounding the recognition and measurement of financial and non-financial contracts.

\section{PRINCIPLES OF THE TRADITIONAL ACCRUAL BASIS OF ACCOUNTING}

The IASB's Framework for the Preparation and Presentation of Financial Statements (Framework) does not specifically refer to the accounting of contracts; it only refers to transactions and events. The basic principles of the accrual basis of accounting are that transactions or events should be recognised when they meet the definition of an element and the recognition criteria of probability and measurability (IASB, 2005a:par. 83). The effect of this application of the Framework is that transactions and events in contracts should be identified to establish the accounting treatment of each individual contract.

\subsection{The definition of assets an liabilities}

The direction that accounting has followed in the last few years is to focus on the balance sheet approach (See Bullen \& Crook, 2005:7; Ernst \& Young, 2005:98; IASB, 2006b). It is therefore considered that meeting the Framework's definitions of assets and liabilities is the first step in the recognition process (Bullen \& Crook, 2005:11), although the Framework (IASB, 2005a:par. 50) specifically states that the definitions of assets and liabilities identify their essential features but make no attempt to specify the criteria needed to be met before they are recognised in the balance sheet.

This first step in the recognition process is therefore the evaluation of the criteria of the definition of an asset (IASB, 2005a:par. 49), which are: 
- a resource;

- controlled by the entity;

- resulting from a past event; and

- from which future economic benefits are expected to flow.

The problematic issue with these criteria is that, except for the criteria of future economic benefits (IASB, 2005a:par. 53), the other criteria are not defined or explained in the Framework. Specifically, the Framework is not particularly helpful in resolving issues concerning the criteria associated with controlled by the entity, where more than one party has some aspect of control over the same asset (Bullen \& Crook, 2005:9). Ernst \& Young (2005:95) confirm the stated concern:

\footnotetext{
"That both the FASB and IASB have a flawed definition at the heart of their conceptual frameworks. If the definition of an asset is flawed the entire logic structure derived from it is too, including all the remaining definitions of the elements of financial statements that depend on the asset definition".
}

Nevertheless, the framework is clear that only past transactions or other events (IASB, 2005a:par. 58), and not transactions or events expected to occur in the future, give rise to assets. The identification of past transactions or other events in contracts could be seen as a critical element to the recognition of any contract for accounting purposes.

In contrast, more information is provided in the Framework on the criteria of a liability (IASB, 2005a:par. 49), which are:

- a present obligation of an entity;

- arising from a past event;

- the settlement of which;

- is expected to result in an outflow of resources; and

- embodying economic benefits.

An obligation is explained as "a duty or responsibility to act or perform in a certain way" (IASB, 2005a:par. 60). The Framework (IASB, 2005a:par. 61) states that a distinction needs to be drawn between a present obligation and a future commitment. The example given (IASB, 2005a:par. 61) is that "an obligation normally arises only when the asset is delivered or the entity enters into an irrevocable agreement to acquire an asset". In the author's view, the concept of an irrevocable agreement has never been applied in accounting to trigger the recognition, except for financial instruments to which fair value accounting is applied. Recognition has always been triggered by identifying the past event. Similar to the definition of an asset, the present obligation must result from past transactions or events (IASB, 2005a:par. 63). The Framework again does not explain this criterion; it only provides limited examples. In this regard, Bullen and Crook (2005:9) state that both the IASB and the FASB have sometimes, in considering standards for obligations that result from a series of events, struggled to identify which event or transaction creates the obligating event.

\subsection{The recognition criteria}

Once the definitions of elements are met, the Framework (IASB, 2005a:par. 83) declares that the 
recognition criteria of probability and measurability should be assessed before an element can be recognised. In the discussion of financial instruments and other IASB projects below, it will be demonstrated that sufficient issues are encountered with both these recognition principles.

\subsection{Measurement guidance}

It is a stated fact that the Framework does not provide sufficient guidance to establish concepts of measurement (Wells, 2003:273). No guidance is provided on the principle of fair value accounting since the fair value concept was developed after the establishment of the Framework in April 1989.

\section{THE PRINCIPLES OF ACCOUNTING FOR FINANCIAL INSTRUMENTS}

Accounting for financial instruments has introduced the concept of the contract basis of accounting (Bradbury, 2003:390). The Financial Instrument Discussion Paper proposed "that there is a powerful logic for adopting an integrated set of principles based on recognition of financial assets and financial liabilities at their fair value at the time that an enterprise becomes a party to a contract and ongoing measurement at fair value" (IASC, 1997:13). The question could be raised whether the approach to recognised financial instruments at contact entry has changed the traditional accrual basis of accounting. The Financial Instrument Discussion Paper (IASC, 1997:13) rejects this idea and states that the "proposed accounting may be thought of as a natural extension of the traditional accrual accounting model, adapted to fit current business and economic circumstances". This natural extension is created through changes in the financial environment, with the Financial Instrument Discussion Paper (IASB, 1997:13) specifically stating that "these principles reflect the realities of capital markets, rational financial risk management practices and investment decision practices", all realities which are not addressed by the Framework.

Reasons for developing the principles for the accounting for financial instruments, as stated in the Financial Instrument Discussion Paper, are firstly, that not many financial derivatives were recognised in financial statements, and secondly, that the historical cost system for financial assets and financial liabilities "lacks relevance and information for investors attempting to evaluate enterprise performance, liquidity and financial risk exposure" (IASB, 1997:13).

\subsection{Extension of the traditional accrual basis}

The author believes that although there is merit in stating that the accounting of financial instruments is a natural extension of the traditional accrual basis of accounting and that it creates more relevant information, the effect of the financial instrument principles is that different contracts are assessed differently for accounting purposes, based on whether the contract is identified as a financial instrument or not. Financial contracts are recognised when an entity become a party to the contract, in other contracts the transactions in the contracts are recognised. The author believes that applying this fixed rule to the recognition of financial contracts results in the effect that each of the following concepts of the traditional accrual basis of accounting need not be assessed in order to recognise an identified financial asset in a contract:

- Identifying a "resource" 
- Establishment of "control"

- Identification of the "past event"

- Assessing the "future economic benefits"

- Applying the recognition criterion of "probability"

- Applying the recognition criterion of "measurability".

The challenges for the recognition of financial assets are thus much lower, that is, if the definition of a financial asset is met, the contract should be recognised from the date the entity enters into the contract. In contrast, non-financial contracts are still subjected to the traditional accrual accounting rules.

The Financial Instrument Discussion Paper discusses the reasons why it is assumed that the above traditional accrual accounting rules are, in fact, met for financial assets. The Financial Instrument Discussion Paper (IASC, 1997:48) declares that the three essential criteria of the definition of an asset, leaving aside the "resource" concept for the moment, are met when the contract is entered into. Control over the potential future benefits is determined by the contract. The past event occurs when the entity becomes a party to the contract. The underlying contract establishes the enterprise's rights to the economic benefits that represent the financial asset. The future economic benefits are established by the contractual right to received cash or another financial asset, or to exchange financial instruments with another party as defined by the definition of a financial asset. This explanation of a contractual right is included in the standard's definition of a financial asset (IASB, 2005a:IAS 32).

The result of these arguments is that it is assumed that the definition of an asset in the Framework has been met when a contract of an entity complies with the definition of a financial asset. Similarly, with respect to financial liabilities the Financial Instrument Discussion Paper proposed the following (IASC, 1997:49):

"With respect to a financial liability, the expected outflow is defined by the contract, and the past event is the act of becoming a party to the contract. Upon being subject to the contract, the enterprise has little, if any, discretion to avoid the outflow of resources specified in it".

\subsection{Recognition criteria}

Both the recognition criteria of "probability" and "measurability" have been rejected. Regarding the recognition criteria of "probability", the Financial Instrument Discussion Paper specifically states that for financial instruments, probability is "a matter affecting its valuation rather than its recognition" (IASC, 1997:49). Furthermore, the Financial Instrument Discussion Paper (IASC, 1997:59) declares that "no exemption for recognition should be given on the grounds of measurability uncertainties".

The result of the implementation of this fixed rule for the recognition of financial instruments is that the involvement in a contract triggers the accounting recognition, provided the contract (except for specific inclusions or exclusions) meets the definition of a financial asset or financial liability. Conditional rights or obligations are therefore included in the scope of financial instruments (IASB, 2005a:IAS 32: par. AG8). It is this focus on the contractual conditions that is seen as a move away from the traditional accrual basis of accounting (Bradbury, 2003:390). 


\subsection{Measurement}

In contrast to recognition, the measurement of financial instruments is more troublesome. As stated above, uncertainty about the probability and measurability is included in the measurement of the fair value of the instrument. Currently, all financial instruments should initially be recognised at fair value (IASB, 2005a:IAS 39: par. 43). This might be seen as a move away from the principle of the Framework (IASB, 2005a:par. 100(a)) which states that assets are recorded at the amount of cash, cash equivalents or the fair value of the consideration given. However, IAS 39 creates a presumption that the fair value of financial instruments on initial recognition is the transaction price (IASB, 2005a:IAS 39: AG64), the fair value of the consideration given or received. IAS 39 further requires that the fair value of the financial instrument on initial recognition need only be estimated in two independent circumstances: when something else is included in the financial instrument (IASB, 2005a:par. AG64) or the requirements of a "day-one" profit or loss have been met (IASB, 2005a:par. AG76). Uncertainty about the application of fair value on initial recognition has prompted the IASB to undertake a project and the resulting exposure draft proposes that all financial instruments must initially be recognised at fair value (IASB, 2005c).

Furthermore, a mixed measurement model is being applied to the subsequent measurement of financial instruments. Currently, financial instruments are subsequently recognised at fair value through the income statement in only three situations. The first situation is based on a fixed rule (derivatives in the scope of IAS 39 should be recognised at fair value), the second is based on intention (the intention to hold financial instruments for trading or reselling purposes), and the third is based on designation (the option to designate certain financial instruments at fair value through profit or loss) (IASB, 2005a:par. 9 read with par. 46 and 47). The concept of recognising all financial contracts at fair value is therefore not applied to all financial instruments.

\section{PROPOSED CHANGES BY THE LIABILITY PROJECT}

In June 2005, the IASB (IASB, 2005b) issued an exposure draft, Amendment to IAS 37 Provisions, Contingent Liabilities and Contingent Assets (hereafter the Non-Financial Liability ED), which reviewed the recognition and measurement criteria for non-financial liabilities. This NonFinancial Liability $\varepsilon D$ confirms the principles of executory and onerous contracts. However, this $\varepsilon D$ alters the effect of recognising liabilities in non-financial contracts significantly by excluding the probability recognition criterion, changing the application of the Framework's definition of liabilities, establishing new rules to recognise uncertainties (contingencies) and eliminating the concept of contingent liabilities.

\subsection{Probability recognition criterion}

The effect of excluding the probability recognition criterion (IASB, 2005b:par. 11) is that a nonfinancial liability will now only be recognised if it meets the definition of a liability, unless the non-financial liability cannot be measured reliably. Reliable measurability thus remains, in contrast to financial contracts, a recognition hurdle for non-financial contracts. As a consequence, only uncertainty about whether a liability exists or whether the amount is reliably measurable will hamper the recognition of a liability. Uncertainty about the amount and timing of the economic benefits of non-financial liabilities will be reflected in the measurement of that liability. 
The IASB proposed the exclusion of the probability recognition criterion because (IASB, 2005b):

- in many cases there is little or no uncertainty that settlement of the obligation will require some outflow of resources (par. BC37);

- the probability recognition criterion was sometimes applied to the 'wrong' obligation: the conditional rather than the unconditional obligation (par. BC40);

- the Framework requires an entity to determine whether a liability exists before considering whether the liability should be recognised (par. BC 41); and

- stand-ready obligations would require an outflow of resources (par. BC43).

Many respondents to the Non-Financial Liability ED (IASB, 2006a:par. 47) disagreed with the proposal on the grounds that the probability recognition criterion is derived from the Framework. As a result of the response, the IASB has re-debated the issue, and although a final conclusion will only be reached later, it has instructed the staff not to include the probability recognition criterion in the final revised IAS 37. In the re-debate the Board has taken the view that (IASB, 2006a:par.48):

- The probability recognition criterion does not relate to determining whether a liability existed;

- The 'more likely than not' threshold only exists in IAS 37 and not in the Framework;

- Once a liability is identified, using the Framework's definition of a liability, the outflow of resources would be probable; the probability recognition criterion will thus not be a determinant of recognition; and

- The probability recognition criterion is inconsistent with the proposed measurement requirements, which should include all possible outcomes.

Other respondents to the Non-Financial Liability ED (IASB, 2006a:par. 34) have noted that the Framework's definition of a liability anticipates a degree of certainty due to use of the wording "expected to" and therefore argue that obligations, with a remote or low likelihood of future settlement, would not meet the definition of a liability. The IASB consequently clarified this issue by stating that "expected to" is not intended to imply that there ought to be a particular degree of certainty that an outflow of benefits will occur before an item meets the Framework's definition of a liability (IASB, 2006a:par. 35).

\subsection{Application of the definition}

As stated above, the Non-Financial Liability ED did not change the Framework definition of a liability, but the application thereof. The wording "a past event is deemed to give rise to a present obligation if, taking account of all available evidence, it is more likely than not that a present obligation existed at the balance sheet date" (IASB, 2005a:par. 15) and "A past event that leads to a present obligation is called an obligating event" (IASB, 2005a:par. 17) was revised to "An essential characteristic of a liability is that an entity has a present obligation arising from a past event. For a past event to give rise to a present obligation, the entity must have little, if any, discretion to avoid settling it. A past event that creates a present obligation is sometimes referred to as an obligating event" (IASB, 2005b:par. 13). The effect of the amended wording is that the test of uncertainty - "the more likely than not" test - is replaced by "an entity must have little, if any, discretion to avoid settling it". 


\subsection{Recognising uncertainties}

To resolve uncertainties, the Non-Financial Liability $\varepsilon D$ introduced new concepts of "contingencies", "unconditional" and "conditional" obligations, and "stand-ready" obligations. A contingency (IASB, 2005b:par. 22) is a liability whose settlement amount is contingent (or conditional) on the occurrence or non-occurrence of one or more uncertain future events. A contingency can be divided into two obligations: an "unconditional" and a "conditional obligation" (IASB, 2005c:10). The unconditional obligation creates the liability (IASB, 2005b:par. 23) and the conditional obligation determines the amount that will be required to settle the liability (IASB, 2005b:par. 23). The test to establish whether a liability exists is the identification of an unconditional obligation and if an unconditional obligation exists, the contingency is reflected in the measurement of the liability (IASB, 2005c:12). Therefore, the recognition of non-financial contracts differs from financial contracts in this respect, as contingent obligations are not recognised.

The new proposal also introduces the new concept of "stand-ready" obligations (IASB, 2005b:par. 24), which are unconditional obligations to stand ready to fulfil the conditional obligations should uncertain future events occur or fail to occur. Respondents argued (IASB, 2006a:par. 44) that the explanation of a stand-ready obligation was too broad and would result in certain business risks being recognised. In response, the IASB has confirmed that the standready obligation must meet the definition of a liability (IASB, 2006a:par. 45) and has instructed the staff to collaborate with the conceptual framework project team to develop additional examples and to differentiate stand-ready obligations from a general business risk (IASB, 2006a:par. 46). The concept of "irrevocable agreement", stated in the Framework (IASB, 2005a: par. 61), could be clarified here. The question is whether an irrevocable agreement would create a stand-ready obligation.

\subsection{Measurement}

The Non-Financial Liability $\varepsilon D$ also creates a new measurement rule, viz. "An entity shall measure a non-financial liability at the amount that it would rationally pay to settle the present obligation or to transfer it to a third party on the balance sheet date" (IASB, 2005b:par. 29). The measurement requirement could be seen as a means to determine the fair value of the liability. Owing to the potential lack of observable market evidence, measurement may be based more upon estimations by and judgement of management (IASB, 2005:par. 30 and 32). This means that, in contrast to fair value rules for financial contracts, the valuation of liabilities in nonfinancial contracts is more reliant upon the judgement of management.

\subsection{Executory contracts}

Through continued application of executory contract principles (IASB, 2005b:par.2), performance still plays a role in the recognition of liabilities in non-financial contracts. Only if the contract is onerous, viz. the unavoidable cost of meeting the obligations exceeds the expected economic benefits thereof, shall the unperformed obligation under the contract be recognised immediately (IASB, 2005b:par. 55).

\subsection{Differences with financial contracts}

The effect of the proposal of the liability project is that the accounting of non-financial 
contracts still differs significantly from that of financial contracts. Under financial contracts, rights and obligations in the contract are assessed to identify the existence of a financial liability contract, which would immediately trigger recognition. Under non-financial contracts, the traditional concept of accrual accounting will still be followed and liabilities in nonfinancial contracts will only be recognised when each present obligation arises from a past event. The exclusion of the probability recognition criterion would result in certain obligations which had not previously been recognised, due to the more than $50 \%$ threshold, now being recognised. For non-financial contracts, the unit of account is not the contract itself, except where the contract is onerous.

\section{PROPOSED CHANGES BY THE REVENUE RECOGNITION PROJECT}

The Financial Instrument Discussion Paper (IASC, 1997:56) states that recognition principles are not defined sufficiently in accounting literature. These recognition principles were developed primarily with traditional revenue-generating operations in mind. New developments in revenue-generating operations, weaknesses in the existing pronouncements and convergence (IASB, 2006b:par. 3) have prompted the IASB to conduct a joint project with the FASB on revenue recognition.

Specifically, IAS 18 does not provide sufficient guidance (IASB, 2006b:par. 3) on contracts which provide multiple goods or services, or how such elements should be divided in components or the related revenue allocated. In correspondence with the principles of the IASB's Framework, a balance sheet approach is proposed (IASB, 2006b:par. 11) for the recognition of revenue which identifies the separate liabilities "performance obligations" that arise from contracts. The emphasis of the revenue project on recognition of the rights and obligations in revenue contracts and their probable recognition at fair value accentuates afresh the accounting treatment of contracts. It seems that for the first time, the IASB is truly assessing the rights and obligations contained in contracts to determine their accounting effect, and not merely relying upon the established principles of the accrual accounting system. In the author's view, this might instigate a significant shift in future accounting treatments of contracts, necessitating accountants to understand the legal principles of contract interpretation so as to comprehend and appropriately account for the rights and obligations in contracts.

\subsection{Recognising rights and obligations}

The revenue recognition project proposes two overall guidelines for the recognition of rights and obligations in revenue contracts. The first is in accordance with the principles of the liability project as discussed above, that conditional rights and obligations do not meet the definition of assets and liabilities, but that unconditional and mature rights and obligations, however, may meet those definitions (IASB, 2006b). The second is that only enforceable obligations should be included in the scope of the revenue recognition project (IASB, 2006b). The revenue project can thus be deemed an extension of the liability project.

The first guideline, the recognition of unconditional and mature rights, raised questions as to whether rights or obligations in revenue contracts could be recognised before any revenue has been recognised. This once again brings the principle of wholly executory contracts and related performance to the fore. The answer to the aforementioned question lies in the unit of account applied to contracts. The IASB agreed at its July 2003 meeting that the unit of account should be 
the assets and liabilities arising from the rights and obligations in the contract (Deloitte, 2007). However, in its December 2003 meeting the IASB noted that the unit of account is determined by the breaching clauses contained in the related revenue contracts (Deloitte, 2007).

Should the legal remedy for a breach of contract be money damages, the unit of account should be the contract as a whole (IASB, 2006b). In instances of money damages for breaches, the only outcome that might occur from settling the contract before performance has occurred is the flow of cash in one direction. The effect thereof is that one party has a pre-performance asset and the other a pre-performance liability; the unconditional rights and obligations exist until the parties have performed the stated conditional obligations. Such contracts (IASB, 2006b) are considered similar to financial assets that can be settled net in cash. The result is that the net amount of such contracts is recognised (Deloitte, 2007).

Conversely, if the legal remedy for the breach of a contract is specific performance (Deloitte, 2007: December 2003 IASB meeting), the legal remedy renders unconditional rights of performance of the items specified in the contract. The settling of such contracts at any time effects a two-way flow of resources, with the creation of correspondent assets and liabilities for each party. As a consequence, the unit of account for each party will be an individual asset and a liability, recognised on a gross basis (IASB, 2006b).

The debate whether assets and liabilities arise in an executory contract was again discussed in the February 2006 meeting (Deloitte, 2007) and the IASB confirmed that rights and obligations do arise.

The inclusion of concepts, i.e. conditional and unconditional rights, mature rights, enforceable obligations and legal remedy of breaching clauses in the revenue recognition project to establish the appropriate accounting treatments for such contracts, denotes a new trend in accounting: accountants now need to know how to evaluate and interpret contracts. The legal principles surrounding the interpretation of contracts (Cornelius, 2002) could thus play a significant role in the future accounting treatment of contracts. Other decisions taken by the IASB also corroborate the requirements of a more detailed comprehension of the provisions of contracts. "Cancellation-like" provisions, such as rights of return, rights of refund or customer acceptance clauses, should for instance also be evaluated and side agreements should be assessed.

\subsection{Measurement of obligations}

In respect of measurement (IASB, 2006b), two approaches are considered: the performance obligations may either be measured at fair value or through allocation of the customer consideration. Currently, the IASB prefers the customer consideration method; the fair value method is, however, more in accordance with the proposal of estimating obligations as set out in the liability project above.

The IASB initially stipulated that performance obligations in revenue contracts should be fair valued in accordance with the liability project, but they have changed their decision to explore a revenue recognition approach, based on the allocation of the customer consideration (IASB, 2006b). Dobler and Hettich (2006) have scrutinised the fair value approach for recognition of performance obligations from a conceptual, analytical and empirical research viewpoint. They conclude that the fair value model conflicts with the quality characteristics and the financial objectives of the IASB's Framework. The allocation of customer considerations (IASB, 2006b) establishes that revenue arises when each contract deliverable (or performance obligation) is 
delivered (or extinguished), thus substantiating the performance basis of accounting. Currently, the Boards are considering whether acceptance by the customer is a prerequisite for recognition revenue (IASB, 2006d). The argument is that legal remedy for breach could be limited to specific performance agreed upon, which may include acceptance, or be based on all performance to date. From the most recent discussions (IASB, 2006d), it is apparent that acceptance will only hinder the recognition of revenue when no legal remedy is available in the event of breach of the contract. Breaching clauses again appears to be decisive in the revenue recognition process.

The IASB is also considering whether unconditional stand-ready obligations and other liabilities, which are recognised at fair value in terms of other IFRSs, should be included in the allocation of the customer consideration. Currently, the IASB (2006b), in contrast to the FASB (2006), has decided that unconditional stand-ready obligations should be recognised as liabilities, and not included in the revenue allocation. The effect of no revenue being allocated to these obligations may result in all revenue being recognised before these obligations occur. The fundamental question to be resolved is whether revenue should be allocated or deferred until such obligations are met.

\section{FRAMEWORK PROJECT}

The Framework Project consists of several stages of which especially the second, elements and recognition, and third, measurement, should impact significantly on the debate of the accounting of financial and non-financial contracts. The effect on the debate of the tentative decisions reached on phases one and two up till September 2007 is discussed below. Phase three has not been taken far enough to prompt any comment at this stage.

\subsection{Phase 1: Objective and qualitative characteristics}

The Discussion Paper on phase 1, Preliminary Views on an improved Conceptual Framework for Financial Reporting: The Objective of Financial Reporting and Qualitative Characteristics of Decision-useful Financial Reporting Information, has broadened the traditional accrual basis of accounting by including the word "circumstances". This Framework Discussion Paper (IASB, 2006e:par. OB 19) proposes that accrual accounting attempts to reflect the financial effects of transactions, other events and circumstances that have cash (or other) consequences for an entity's resources and the claims to them in the period wherein they occur or arise. The author foresees the broader identification of accrual accounting to include all circumstances in which the unit of account will be regarded to entail the contract as a whole.

\subsection{Phase 2: Elements and Recognition}

The tentative decisions taken in the second phase of the Framework project proposed new definitions for assets or liabilities. The proposed working definition of an asset is the following (FASB \& IASB, 2007): "An asset is a present economic resource to which an entity has a present rights or other privileged access". Interestingly, all the requirements of the Framework's definition of an asset that were assumed to be met for financial contracts - control, past event and future economic benefits - have been abolished in the new proposed definition.

The second phase of the Framework project proposes three essential characteristics of an asset (IASB, 2006c and FASB \& IASB, 2007): 
- A present economic resource.

- A present right or other privileged access to the economic resources.

- Both the economic resources and the rights or other privileged access exist at the financial statement date.

The words "present economic resource" create the flipside for the "present economic obligations". However, in the author's view, the concept of "resources" is much wider than the concept "obligation" in the sense that it includes not only rights, but also direct ownership. An economic resource is regarded as something that has a positive economic value (FASB \& IASB, 2007). This raises the question whether all beneficial contracts will meet this requirement and should be recognised for accounting purposes.

In the tentative decisions the concept of economic resource is discussed further (FASB \& IASB, 2007). Firstly, it is scarce and capable of being used to carry out economic activities such as production and exchange. Secondly, it can contribute to producing cash inflows or reducing cash outflows, directly or indirectly, alone or together with other economic resources. The question is whether this will include purchase and sale contracts, which could result in the contracts be recognised earlier.

This has partially been considered in the third tentative explanation, which states that economic resources include non-conditional contractual promises that others make to the entity, such as promises to pay cash, deliver goods, or render services. Therefore, it seems that future promises in purchase and sale contracts could be recognised for accounting purposes, if they are not conditional. The effect of not recognising executory contracts in the case of non-financial contracts might be removed. This is also confirmed in the last tentative decision, which states that rendering services includes standing ready to perform or refraining from engaging in activities an entity could otherwise undertake.

The tentative decisions state that a right or other privileged access enables the entity to use the present economic resource directly or indirectly and precludes or limits its use by others. Further, rights are both legally enforceable and enforceable by other means. In contrast, other privileged access is not enforceable, but is otherwise protected (FASB \& IASB, 2007).

The proposed definition of a liability (FASB \& IASB, 2007) is the opposite of the definition of an asset: "A liability is a present economic burden for which the entity has a present obligation". Like the definition of an asset, both the present economic burden and the obligation must occur on the date of the financial statements (FASB \& IASB, 2007). This proposal also removes past terminology such as "past event", "settlement" and "outflow of resources" (IASB, 2005a).

An economic burden is regarded as something that has negative economic value (FASB \& IASB, 2007). Therefore, it should include the current concept of onerous contracts. The economic burden is similar to an economic resource further discussed in the tentative decisions (FASB \& $I A S B$, 2007). Firstly, it is capable of requiring the sacrifice of economic resources. Secondly, it can alone or together with other economic burdens require cash flows or reduces cash inflows, directly or indirectly. Thirdly, it includes non-conditional contractual promises made to others, such as promises to pay cash, deliver goods, or render services. This is in line with the liability project, which states that only non-conditional obligations should be recognised. The question is whether the word "promises" is wider than obligations and would, therefore, broaden the scope.

An obligation could also be direct or indirect, and is legally enforceable or enforceable by other 
means (FASB \& IASB, 2007).

Generally, all contracts that are entered into will include certain rights and obligations to act or to perform. Does this mean that all such obligations should be recognised initially, provided they are not conditional? Clarity about what is meant by the phrases 'present' and 'conditional' is needed. This clarity should also, in the author's view, provide guidance so as to determine when the unit of account entails the contract as a whole or merely the disaggregated parts. It is furthermore important to identify the differences between an obligation to provide future economic resources to others, and the obligation to stand ready to do so.

\section{CONCLUSION}

This paper substantiates the existence of differences between the recognition of contracts under the contract basis applied for financial instruments and contracts recognised in terms of the traditional accrual basis of accounting. For contracts of financial assets, it is assumed that the "control", "past event" and "future benefits" requirements are met when the contracts are entered into. In addition, for financial liability contracts, it is comparably assumed that the "obligation", "past event" and "outflow of resources" requirements are also met. Non-financial contracts should, however, still follow the process of identifying these requirements of the definitions in the Framework.

This difference in application between financial and non-financial contracts is also discussed in the revenue recognition project along with the concept of the unit of account regarding either the whole contract or the disaggregated portions. In the revenue project, this differentiation is based on the interpretation of the breaching clauses in the contract. If monetary damage is provided for breach of contracts, the unit of account should be the contract as a whole; the net value of such rights and obligations are recognised up-front. If specific performance is required for legal remedy of breaching clauses, the individual rights and obligations in the contract will create separate assets and liabilities. The FASB and IASB therefore agree that individual assets or liabilities could arise in whole executory contracts. This confirms in principle that for financial contracts the unit of account is the contract as a whole and for other contracts it is the assets and liabilities created in the contracts.

A new approach is considered in the Framework project in which the implications of promises in contracts are discussed. This could signal an end to the concept "executory contracts". It is therefore of the utmost importance that new concepts in the Framework project, such as "economic resources", "present rights", "privileged access" and "economic obligations" be thoroughly investigated and motivated before implementation. Situations should be avoided where concepts in the Framework's definitions are not adequately explained.

Fortunately, the concept "present obligation" has been explained more thoroughly in the liability project, especially in instances of uncertainty. New concepts such as "conditional", "unconditional" and "stand-ready" obligations have been identified and explained in the liability project, and "mature" obligations in the revenue recognition project. In response to the comments received on the Non-Financial Liabilities $\varepsilon D$, the IASB has already started re-debating issues identified with these concepts. The effect is that a thorough debate and understanding of these concepts is essential to establish an appropriate accounting treatment for non-financial obligations in contracts. The possible recognition of promises in contracts, considered in the Framework project, could even alter these concepts. 
A further concern expressed is that it appears that accountants are required to be experts on the legal rules of interpretation of contracts in order to apply the new philosophy in accounting. The recognition emphasis in the new projects focuses more on the identification of the nature of the rights and obligations in contracts. Legal concepts - i.e. rights and obligations, enforceable, cancellation provisions, legal remedy for breach, express or implied, side-agreements, obligated to act or perform and promises - filter through the new projects.

With respect to measurement, the choice available between the fair value and the allocation of consideration methods for revenue recognition proves that the borders for the use of fair value in accounting of contracts have not yet been clearly demarcated. Although fair value appears to be appropriate for the recognition of contracts for which the unit of account is the whole contract, not all financial contracts are recognised at fair value. Furthermore, although a fair value model based more upon increasing management input is proposed for non-financial liabilities, fair value does not appear to be the appropriate method of spreading performance obligations in revenue contracts. The issue of whether stand-ready obligations in revenue contracts should be recognised as liabilities at fair value or form part of the allocation of revenue also needs to be resolved.

The last word on the recognition of contracts for accounting purposes has not been written. This article considers the real debate to have merely commenced. Fundamental issues will have to be resolved prior to the resolution of the liability, revenue recognition and framework projects.

\section{REFERENCES}

Bradbury, M.E. (2003). Implications for the Conceptual Framework arising from Accounting for Financial Instruments. ABACUS, 39(3), p. 388-397.

Bullen, H.G. \& Crook, K. (2005). Revisiting the Concepts: A New Conceptual Framework Project. May 2005. London: IASB. Available from: http://www.fasb.org/project/communications_paper.pdf. (Accessed on 16 October 2005).

Coetsee, D. (2006). A critical review of the effect of accounting for financial instruments on the accounting framework. South African Business Review, 10(3), p. 115-129.

Cornelius, S.J. (2002). Principles of the Interpretation of Contracts in South Africa. Durban: LexisNexis Butterworths.

Deloitte (2007). IASB Agenda Project: Revenue Recognition. Available from: http://www.iasplus.com/agenda/revenue.htm (Accessed on 17 October 2007).

Dobler, M. \& Hettich, S. (2006). Rethinking Revenue Recognition - Critical Perspectives on the IASB's Current Proposals. Ludwig-Maximilians-Munich University: Munich Business Research.

Ernst \& Young (2005). International GAAP 2005. London: LexisNexis.

Financial Accounting Standards Board (FASB) \& International Accounting Standards Board (IASB)

(2007). Project Update: Conceptual framework: Summary of Tentative Decisions (Updated through October 9, 2007). Available from:

http://www.fasb.org/project/conceptual_framework.shtml. (Accessed on 15 0ctober 2007). 


\section{$D$ Coetsee}

Financial Accounting Standards Board (FASB) (2006). Project update: Revenue recognition. Last updated: August 4, 2006. Available from:

http://www.fasb.org/project/revenue_recognition.shtml. (Accessed on 07 September 2006).

International Accounting Standards Committee (IASC) (1997). Accounting for Financial Assets and Financial Liabilities: A Discussion Paper issued for comment by the Steering Committee on Financial Instruments. March 1997. London: IASC.

International Accounting Standards Board (IASB) (2005a). International Financial Reporting Standards (IFRSs) including International Accounting Standards (IASs) and Interpretations as at 30 November 2005. London: IASB.

International Accounting Standards Board (IASB) (2005b). Exposure Draft: Amendments to IAS 37 Provisions, Contingent Liabilities and Contingent Assets and IAS 19 Employee benefits. Latest revision: June 2005. Available from: http://www.iasb.org/NR/rdonlyres/lCFBClA8-50Fl-4BF39A33-579F849560C8/0/EDAmendstolAS37.pdf. (Accessed on 07 September 2006).

International Accounting Standards Board (IASB) (2005c). Project Update: Amendments to IAS 37 Provisions, Contingent Liabilities and Contingent Assets. May 2005. Available from: http://www.iasb.org/Current+Projects/IASB+Projects/Liabilities/Liabilities.htm. (Accessed on 07 September 2006).

International Accounting Standards Board (IASB) (2005d). Discussion Paper: Measurement Bases for Financial Accounting - Measurement on Initial Recognition, November 2005. London: IASB.

International Accounting Standards Board (IASB) (2006a). Project Summary: Liabilities: Amendments to IAS 37 Provisions, Contingent Liabilities and Contingent Assets and IAS 19 Employee benefits. Latest revision: July 2006. Available from:

http://www.iasb.org/Current+Projects/IASB+Projects/Liabilities/Liabilities.htm. (Accessed on 07 September 2006).

International Accounting Standards Board (IASB) (2006b). Projects Summary: Revenue Recognition. Updated 10 March 2006. Available from:

http://www.iasb.org/Current+Projects/IASB+Projects/Revenue+Recognition/Revenue+Recogniti on.htm. (Accessed on 07 September 2006).

International Accounting Standards Board (IASB) (2006c). Project Summary: Conceptual Framework - Joint Project of the IASB and FASB. Available from:

http://www.iasb.org/Current+Projects/IASB+Projects/Conceptual+Framework/Conceptual+Fram ework.htm. (Accessed on 07 September 2006).

International Accounting Standards Board (IASB). (2006d). IASB UPDATE, July 2006. Available from: http://www.iasb.org/NR/rdonlyres/380AFB66-0EC3-42BD-9CAC-6145B95165F2/0/jul06.pdf. (Accessed on 07 September 2006).

International Accounting Standards Board (IASB) (2006e). Discussion Paper: Primary Views on an improved Conceptual Framework for Financial Reporting: The Objective of Financial Reporting and Pualitative Characteristics of Decision-useful Financial Reporting Information. July 2006. London: IASB.

International Accounting Standards Board (IASB) (2006f). IASB UPDATE, June 2006. Available from: http://www.iasb.org/NR/rdonlyres/469EC326-A916-4FBB-A63D-2DFEDBF70247/0/june06.pdf. (Accessed on 07 September 2006). 
DEBATING THE METHODOLOGIES OF ACCOUNTING FOR FINANCIAL AND NON-FINANCIAL CONTRACTS

Wells, M. (2003). Forum: The Accounting Conceptual Framework: Introduction. ABACUS, 39(3), p. 273278. 
D Coetsee 